\title{
SYEKH AHMAD KHATIB MINANGKABAU DAN POLEMIK TAREKAT NAQSYABANDIYAH DI NUSANTARA
}

\author{
Ahmad Fauzi Ilyas \\ Sekolah Tinggi Ilmu Tarbiyah Ar Raudlatul Hasanah, Indonesia \\ Jl. Setia Budi, Medan, Sumatera Utara 20132 \\ e-mail: oji.mudo@gmail.com
}

\begin{abstract}
Syekh Ahmad Khatib Minangkabau and Tarekat Naqsyabandiyah Polemic in Indonesia Archipelago. This article describes the intellectual biography of Sheikh Ahmad Khatib Minangkabau, an Indonesian born scholar but spent most of his career in Mecca from the end of the 19th century to the beginning of the 20th and examines his response to the Naqsyabandiah congregation in Indonesia archipelago. Sheikh Ahmad deserves to be studied, considering his significant influence among Muslims of the region. In contrary with some belief, this study reveals that Sheikh Ahmad's works indicate that he was in the opinion that Naqsyabandiyah was in line with orthodox Islam, with the exception of five amaliyah. This study is expected contribute to the study of Islam in Indonesia archipelago.
\end{abstract}

Keywords: Ahmad Khatib Minangkabau, Tarekat, Naqsyabandiyah, Indonesia archipelago 


\section{Pendahuluan}

Syekh Ahmad Khatib Minangkabau merupakan ulama Nusantara yang terkemuka di penghujung abad 19 dan awal abad 20. Peran dan kontribusinya bagi perkembangan keilmuan keislaman tidak dapat diragukan. Banyak gelar dan amanah yang diemban selama hidupnya. Ia adalah ulama pertama asal Nusantara yang diangkat oleh penguasa Haramain untuk menjabat sebagai imam dan khatib di Mesjidil Haram. Selain itu, ia banyak terlibat polemik dengan ulama-ulama semasanya. Namun polemik yang berkepanjangan adalah dalam masalah Tarekat Naqsyabandiyah Khalidiyah di Minangkabau.

Menurut Martin van Bruinessen, tidak diketahui secara pasti kapan Tarekat Naqsyabandiyah Khalidiyah masuk ke Nusantara. ${ }^{1}$ Namun, tarekat ini mempunyai kekuatan sosial di masyarakat ketika kembalinya Syekh Ismail Minangkabau dari Makkah pada permulaan tahun $1850 \mathrm{M}$ ke Nusantara. Meskipun ia berasal dari Simabur di Minangkabau, ia tidak pernah kembali ke daerah asal kelahirannya. Peta perjalanannya adalah Singapura, Riau dan Kedah; sehingga pengaruh-pengaruhnya masih ada di tiga daerah ini. Terkait dengan Minangkabau, Martin van Bruinessen juga belum dapat memastikan awal masuknya tarekat ini ke daerah tersebut. Menurutnya, nama Syekh Jalaluddin Cangking merupakan seorang syekh Tarekat Naqsyabandiyah Khalidiyah yang dikenal pertama sekali di sekitar tahun 1860 . Meskipun tidak kembali ke tanah airnya, setidaknya pengaruh Syekh Ismail Minangkabau sangat besar di daerah ini, sebab para ulamanya ketika belajar di Makkah secara otomatis belajar kepada Syekh Ismail Minangkabau yang sudah dikenal dengan guru Tarekat Naqsyabandiyah Khalidiyah. ${ }^{2}$

Berbeda dengan Martin van Bruinessen, Wan Mohd. Shagir Abdullah memastikan Syekh Ismail Minangkabau pernah kembali ke Simabur, tempat kelahirannya. Bahkan ia menambahkan 


\section{JOIRNAL OF CONTENPORARY ISLAN AND MISSLIM SOCIETIES}

nama-nama sahabatnya yang sama-sama belajar Tarekat Naqsyabandiyah Khalidiyah ketika di Makkah dari ulama-ulama daerah ini, seperti Syekh Jalaluddin Cangking, Syekh Abdurrahman Batu Hampar dan Syekh Mustafa Sungai Pagu. Para ulama-ulama ini yang kemudian melahirkan ulama-ulama Tarekat Naqsyabandiyah Khalidiyah selanjutnya seperti Syekh Muhammad Sa'ad Mungka dan Syekh Muhammad Khatib Ali Padang. Sampai masa ini, keberadaan Tarekat Naqsyabandiyah Khalidiyah di Minangkabau tidak dipermasalahkan. ${ }^{3}$

Meski sudah terjadi perdebatan antara ulama Kaum Tua dan Kaum Muda terkait masalah Tarekat Naqsyabandiyah Khalidiyah, ${ }^{4}$ namun dengan terbit karya Syekh Ahmad Khatib Minangkabau yang kemudian memicu polemik di antara ulama Minangkabau dengan membantah lima amaliyah dalam Tarekat Naqsyabandiyah Khalidiyah yang terbit pada tahun $1324 \mathrm{H} / 1906 .{ }^{5}$ Perdebatan ini berlanjut sampai tiga kali.

\section{Biografi dan Aktivitas Keilmuan}

Nasab dari pihak ayah adalah Syekh Ahmad Khatib bin Syekh Abdul Latif bin Syekh Abdurrahman bin Syekh Abdullah bin Syekh Abdul Aziz. Semua ayah dan kakeknya sampai ke atas adalah seorang ulama besar di daerah Minangkabau. Sementara dari pihak ibu adalah Limbak Urai binti Tuanku Nan Rancak, yang merupakan ulama kaum Paderi. ${ }^{6}$ Lahir di Kota Gadang, Bukittinggi, Sumatera Barat. Mengenai tahun kelahirannya masih diperdebatkan antara penulis biografinya seperti Hamka, Umar Abdul Jabbar dan Deliar Noer. Hamka dan Umar Abdul Jabbar menyebutkan tahun $1860 \mathrm{M} / 1276 \mathrm{H}$, yaitu pada hari Senin, 6 Dzulhijjah, sementara menurut Deliar Noer tahun 1885 M. $^{7}$

Syekh Ahmad Khatib Minangkabau menempuh pendidikan awal informalnya kepada ayahnya sendiri, Syekh Abdul Latif 
yang merupakan ulama dan khatib nagari di daerahnya, Bukittinggi. Kepada ayahnya tersebut, ia mempelajari dasar-dasar agama Islam, seperti membaca Alquran. Selain belajar tentang agama Islam, ia juga belajar bahasa Inggris dengan masuk ke sekolah Meer Uietgebreid Leger Onderwijs (MULO) yang didirikan Belanda pada saat itu.

Ketika berumur 11 tahun, pada tahun $1287 \mathrm{H} / 1870 \mathrm{M}$, ia bersama dengan ayahnya pergi ke Makkah dalam rangka menunaikan ibadah haji. Namun, setelah menunaikan ibadah haji, ia bersama ayahnya tidak langsung kembali ke tanah air, melainkan menetap di kota suci tersebut selama 5 tahun. Pada kesempatan ini, Syekh Ahmad Khatib Minangkabau berkesempatan belajar kepada ulama-ulama besar Makkah. Guru dan Syekh bagi Syekh Ahmad Khatib Minangkabau adalah tiga keluarga Syatha': Syekh Abu Bakar Syatha, Syekh 'Umar Syatha, Syekh 'Utsman Syatha, dan Syekh Sayyid Ahmad Zaini Dahlân'. Amirul Ulum menambahkan Syekh Muhammad Nawawi Banten dalam daftar guru-gurunya. Dengan jumlah gurunya yang tidak sedikit tersebut, dapat menjelaskan bahwa keilmuannya selain diperoleh dari guru adalah secara otodidak. Keotodidakannya dalam belajar dan membaca disebabkan karena mertuanya adalah seorang ulama sekaligus saudagar yang memiliki toko kitab, sehingga, kitab-kitab agama secara lebih mudah dapat diperoleh.

Penguasaannya kepada setiap kitab yang dibaca adalah sebagai bukti dari mimpinya bertemu dengan Rasulullah SAW. di mana, Rasulullah menyuruhnya membuka mulut kemudian meludahkan air ludahnya ke dalam mulut Syekh Ahmad Khatib, sehingga semenjak saat itu, setiap kitab yang dibaca dan ditelaahnya secara lebih cepat dapat dipahaminya lebih mudah. ${ }^{9}$

Mengenai diangkat sebagai pengajar, imam dan khatib di Mesjidilharam, terdapat dua pendapat. Pertama, pengangkatannya tersebut atas usulan dari mertuanya, Syekh Saleh Kurdi yang 


\section{JOIRNAL OF CONTENPORARY ISLAN AND MISSLIM SOCIETIES}

merupakan teman dekat penguasa Makkah saat itu, Syarif Aun. Ini terjadi ketika ada perjamuan makan kerajaan yang dihadiri mertuanya. Ketika pembicaraan terkait mertuanya, penguasa tersebut mengatakan ia diinformasikan bahwa mertuanya menikahkan puterinya dengan seorang Jawi yang tidak menguasai bahasa Arab kecuali setelah belajar di Makkah. Namun, Syekh Saleh Kurdi memberikan jawaban yang singkat dan tepat, dengan menunjukkan alasan diterimanya sebagai menantu karena kesalehan dan ketakwaan Syekh Ahmad Khatib. Kemudian mertuanya menawarkan menantunya sebagai imam dan khatib di Masjidilharam. ${ }^{10}$ Kedua, pengangkatannya sebagai imam dan khatib disebabkan karena seni berorasi yang dimilikinya dan koreksian bacaan imam olehnya pada satu jamaah salat Maghrib yang diimami oleh Syarif Husein. ${ }^{11}$

Halaqah ilmiah banyak dikerumuni penuntut ilmu, terutama dari Nusantara terletak di Bab Ziyadah. Kelebihannya dari ulama lainnya terletak pada cara dan metode mengajar yang bertumpu pada pemahaman dan diskusi. Syekh Ahmad Khatib lebih banyak berdiskusi kepada para muridnya, sehingga peran mereka lebih terlihat aktif. ${ }^{12}$ Menurut Syekh Hasan Maksum, ${ }^{13}$ pengajaran gurunya tersebut secara zahir adalah seperti kebanyakan ulama yang mengajar, namun ketika dilontarkan kepadanya beberapa pertanyaan akan menunjukkan posisinya sebagai ulama ensiklopedis. ${ }^{14}$

Aktivitas keseharian sebagaimana disebutkan Umar Abdul Jabbar dimulai dengan salat Subuh berjamaah di Masjidilharam yang dilanjutkan dengan pengajaran. Kemudian kembali ke rumah untuk sarapan pagi. Selanjutnya, kemungkinan tidur dalam waktu yang singkat dan melanjutkan menelaah kitab sampai waktu Zuhur. Ketika Zuhur, ia pergi salat berjamaah di masjid dan setelahnya kembali ke rumah guna memberikan dua pelajaran kepada murid-muridnya. Kemudian makan siang dan beristirahat sejenak sampai salat Asar, ia pergi ke masjid 
guna melaksanakan salat Asar berjamaah. Setelah salat, ia membuka pelajarannya dan menelaah kitab sampai waktu Maghrib, ia kembali ke masjid guna menunaikan salat Maghrib berjamaah. Setelah memberikan pelajaran sampai waktu salat Isya, ia salat berjamaah dan kembali ke rumah untuk makan malam bersama keluarga. Ia memulai tidur malam di waktu yang cukup awal sampai sepertiga malam, di mana ia bangun dan menggunakan waktu sampai subuh tersebut untuk menulis. ${ }^{15}$

Meski tinggal di Makkah, ia termasuk di antara ulama Nusantara yang secara terus menerus mengikuti informasi Nusantara secara umum, dan tanah kelahirannya, Minangkabau secara khusus. Ia banyak berpolemik dengan beberapa ulama Nusantara terhadap beberapa masalah yang sedang berkembang saat itu. Terkait permasalahan seputar Tarekat Naqsyabandiyah, ia berpolemik dengan Syekh Muhammad Saad Mungka, dan Syekh Khatib Muhammad Ali. Ia juga berpolemik dengan Syekh Sayyid Usman bin Aqil, mufti Betawi terkait kebolehan mendirikan salat Jumat di masjid baru di Palembang. ${ }^{16}$ Selain itu, ia berpolemik dengan dua muridnya dalam dua masalah: dengan KH. Hasyim Asy'ari terkait keabsahan organisasi Sarekat Islam, ${ }^{17}$ dan Syekh Abdulkarim Amrullah dalam persoalan melafazkan niat salat. ${ }^{18}$ Polemik lainnya adalah persoalan hukum warisan yang berlaku di Minangkabau. ${ }^{19}$ Polemik-polemik tersebut tertuang dalam beberapa karyanya.

Selain berpolemik, ia banyak dijadikan sebagai sumber rujukan agama bagi para raja, terkhusus di wilayah Sumatera dan Malaya. Sebab, banyak raja mengirimkan permintaan fatwa terkait permasalahan-permasalan Nusantara, termasuk di antaranya permintaan pembuatan teks khutbah kedua -na'at- salat Jumat dan kedua Idul Fitri dan Idul Adha. Sebab, biasanya pada teks khutbah kedua ada dicantumkan pujian kepada penguasa atau pemimpin Islam yang sedang memerintah negeri tersebut yang dilengkapi dengan bacaan-bacaan doa untuk bilal. ${ }^{20}$ 


\section{JOIRNAL OF CONTENPORARY ISLAN AND MISSLIM SOCIETIES}

Mengenai murid-muridnya, mereka adalah ulama-ulama besar yang mempunyai wibawa dan kedudukan di tengah masyarakat. Sebab, keikhlasan dan kebersamaan guru mereka, Syekh Ahmad Khatib dalam mendidik dan membimbing. Terkait banyaknya murid yang belajar kepadanya, Snouck Hurgronje menulis tentang sosoknya dengan mengatakan bahwa ia-Syekh Ahmad Khatibadalah seorang yang berasal dari Minangkabau, yang oleh orang Jawa di Makkah dianggap sebagai ulama yang paling berbakat dan berilmu di antara mereka, di mana semua orang Indonesia yang berhaji akan mengunjunginya. ${ }^{21}$ Tidak mengherankan apabila jumlah muridnya yang bertambah setiap harinya. Para muridnya, berdasarkan daerah: dari Sumatera Timur adalah Syekh Muhammad Zein Tasak Batu Bara, ${ }^{22}$ Syekh Muhammad Nur (mufti Kerajaan Langkat), Syekh Muhammad Nur Ismail (Kadhi Kerajaan Langkat), Syekh Hasan Maksum (Mufti Kerajaan Deli), Syekh Musthafa Husein (pendiri pesantren Purba Baru), dan Syekh Abdul Hamid Mahmud (pendiri madrasah Ulumil Arabiyah di Asahan). ${ }^{23}$ Sementara dari Sumatera Barat, Syekh Muhammad Jamil Jambek di Bukittinggi, Syekh Muhammad Thayib di Tanjung Sungayang, Syekh Abdullah Ahmad (pendiri sekolah Adabiyah tahun 1912 M dan majalah Al Munir tahun 1911 M) di Padang, Syekh Abdulkarim Amrullah di Padang Panjang, ${ }^{24}$ Syekh Khatib Muhammad Ali, Syekh Sulaiman Rasuli, Syekh Bayang Muhammad Dalil, Syekh Muhammad Jamil Jaho, dan Syekh Taher Jalaluddin. Dari daerah Jawa, KH. Hasyim Asy'ari (pendiri NU), KH. Ahmad Dahlan (pendiri Muhammadiyah), KH. Wahab Hasbullah (salah satu pendiri NU), dan KH. Bisri Syansuri. Dari daerah Malaysia, Syekh Muhammad Saleh (Mufti Kerajaan Selangor), Syekh Muhammad Zein Simabur (Mufti Kerajaan Perak), dan Syekh Muhammad Mukhtar bin Atharid Bogor, termasuk di antara daftar namanama muridnya yang berada di Makkah. ${ }^{25}$ 
Murid-murid setelah kembali dari pelajaran mereka di Makkah, ada yang menempati posisi keagamaan yang tinggi, terutama di daerah yang masih terdapat kerajaan-kerajaan Islam, seperti di Sumatera Timur dan Malaysia. Selain itu, di antara muridnya ada yang dikenal dengan Kaum Tua dan Kaum Muda. Istilah terakhir lebih dikenal di Minangkabau yang cukup mewarnai jalan keagamaan dalam beberapa dekade lamanya.

\section{Karya Tulis}

Syekh Ahmad Khatib Minangkabau termasuk di antara ulama besar Indonesia yang paling produktif menulis. Tulisannya sarat dengan kedalaman keilmuan penulisnya dan sebagian besar merupakan kritik dan bantahannya terhadap permasalahan keislaman yang berkembang di sebagian daerah di Nusantara. Menurut Umar Abdul Jabbar, jumlah karya yang ditulisnya mencapai 46, yang ditulis dalam bahasa Arab dan Jawi. ${ }^{26}$ Sementara menurut Zainal Abidin Ahmad ada sekitar 49 kitab. Semua kitabnya, selain tersebar di Tanah Air juga di Syria, Turki, dan Mesir. ${ }^{27}$

Menurut catatan otobigrafinya, Syekh Ahmad Khatib menulis empat puluh tujuh karya dalam dua bahasa: Arab dan Jawi- 23 dicetak dan 24 masih berbentuk manuskrip. Pendapat ini sekaligus mereduksi semua pendapat-pendapat penulis biografi ulama Nusantara terkait jumlah karyanya yang selalu diperdebatkan. Karya-karya tersebut akan dibicarakan berikut ini dilengkapi dengan alasan penulisan dan tempat pencetakan.

Pertama, al-Nafahat Hâsyiah al-Waraqât, sebuah kitab pertama dari Syekh Ahmad Khatib yang ditulis dalam bahasa Arab, sebagai penjelasan atas kitab al-Waraqât karya Imam Jalâluddîn al-Mahalli yang menjelaskan matan dasar karya Imam Juwainî. Kitab al-Waraqât dalam bidang usul fikih merupakan kitab yang cukup penting bagi dunia Islam, terutama Nusantara. Banyaknya 


\section{JOIRNAL OF CONTEVPORARY ISLAN AND MISSLIM SOCIETIES}

hâsyiah atas kitab ini menunjukkan nilai yang berarti bagi dunia keilmuan Islam. Salah satu kitab yang diajarkan Syekh Ahmad Khatib di halaqah Masjidilharam adalah kitab al-Waraqât, sehingga oleh karena tidak adanya kitab hâsyiah di masanya yang dapat menjelaskan kesulitan memahami uraian dari 'ibarah kitab, ia kemudian menulis kitab ini. Kitab ini diselesaikan penulisannya pada tahun $1306 \mathrm{H}$ dan dicetak berulang kali oleh penerbit. Naskah yang ada sama penulis ada dua, salah satunya cetakan Dâr al-Kutub al-'Arabiyah yang disalin ulang oleh Syekh Jadullah bin Muhammad Badawi pada tahun $1309 \mathrm{H}$.

Kedua, al-Jawâhir al-Naqiyyah fi al-A'mâl al-Jaibiyah dalam bahasa Arab. Kitab ini merupakan karya keduanya dalam bidang ilmu falak ('ilm al-miqat). Sebagaimana disebutkan penulisnya bahwa sebelum menulis kitab ini, ia tidak termasuk expert, bahkan ia belum menemukan guru yang tepat untuk mengajari ilmu tersebut, sehingga atas inisiatifnya ia belajar secara otodidak sehingga mampu menguasai ilmu tersebut. Karena banyak permintaan orang-orang Nusantara kepadanya untuk menulis sebuah kitab dalam bidang ini, ia kemudian menulisnya. Ia menyelesaikannya pada tahun $1309 \mathrm{H}$ dan dicetak oleh Penerbit Matba'ah Maimaniyah di Mesir atas biaya adik iparnya, Syekh Muhammad Majid alKurdi, sebuah pemilik percetakan yang diawal-awal di Makkah, yaitu Mathba'ah al-Taraqqi al-Majidiyah.

Ketiga, al-Dâ'i al-Masmu'fi al-Radd 'alâ Man Yuwarrits alIkhwah wa Aulâd al-Akhawât ma'a Wujûd al-Ushûl wa al-Furu' dalam bahasa Arab. Sesuai dengan judulnya, kitab ini ditulis sebagai bantahan atas amaliyah dan tradisi masyarakat Minangkabau yang sudah turun-temurun terkait pewarisan harta kepada saudara dan kemanakan dengan mengabaikan anak dan orang tua. Kitab ini cukup menggemparkan wilayah Nusantara pada zamannya sehingga menuai kritikan yang keras dari berbagai pihak, termasuk anak-anak muridnya. Penolakan terhadap pewarisan Minangkabau 
juga pernah ditulis oleh Syekh Sayyid Usman Betawi dalam kitabnya, Manhaj al-Istiqâmah fî al-Dîn bi al-Salâmah. Alasan yang mendorong Syekh Ahmad Khatib menulis kitab ini adalah sebuah pertanyaan dari negeri Minangkabau terkait masalah warisan yang berlaku di sana. Pertama sekali, pertanyaan tersebut diajukannya kepada gurunya, Syekh Sayyid Abu Bakar Syatha yang dijawab oleh gurunya tersebut dengan tiga lembar fatwa sebagai jawaban, dan dikirim ke negeri Minangkabau. Namun, oleh karena halaman yang kurang banyak, mereka tidak merasa puas atas jawaban pengarang kitab I'ânah, yang mendorong Syekh Ahmad Khatib menulis kitab ini.

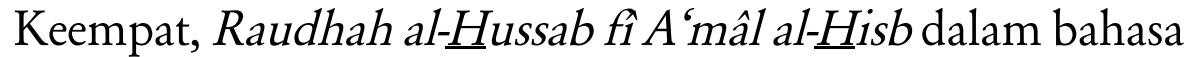
Arab. Kitab ini membahas ilmu perhitungan, al-jabar wa almuqabalah, dan mufâsakhah. Dalam keilmuan berhitung, Syekh Ahmad Khatib juga termasuk di antara ulama yang belajar secara otodidak, seperti penuturannya bahwa ia tidak menemukan guru yang tepat dalam ilmu ini, sehingga ia bersungguh-sungguh dalam mempelajarinya dari kitab-kitab terkait sehingga expert di bidang ilmu tersebut. Setelah selesai menulis kitab ini, ia menunjukkannya kepada gurunya Syekh Abu Bakar Syatha' yang mengapresiasinya secara serius. Kitab ini diterbitkan oleh Matba'ah al-Maimaniyah di Mesir atas biaya temannya, Syekh Muhammad Kasymiri.

Kelima, al-Riyadh al-Wardiyah fi al-Ushûl al-Tauhîidiyah wa al-Furú ${ }^{6}$ al-Fiqhiyah dalam bahasa Jawi. Kitab ini merupakan karya lengkapnya dalam bidang fikih ibadah. Sebab penulisan kitab ini atas permintaan ibunya yang saat itu datang ke Makkah menemuinya untuk belajar dasar-dasar agama. Kitab tersebut diselesaikan pada tahun $1311 \mathrm{H}$ dan dicetak beberapa kali, di antaranya oleh Matba'ah al-Miriyah dan Matba'ah Taraqqi alMajidiyah di Makkah atas biaya adik iparnya. 
JOIRNAL OF CONTEMPORARY ISLAM AND MIISLIM SOCIETIES

Keenam, al-Manhaj al-Masyru'fi Tarjamah al-Da'i al-Masmu' Kitab ini ditulis sebagai terjemahan dari kitab al-Da i al-Masmu“ berbahasa Arab yang oleh karena orang Minangkabau tidak semuanya mengerti bahasa tersebut, mereka memohon kepadanya untuk menerjemahkan ke bahasa mereka dengan menambahkan tulisan dalam bidang ilmu waris dan pembagiannya. Kitab ini selesai ditulis pada tahun $1311 \mathrm{H}$ dan dicetak pada Matba'ah alMaimaniyah di Mesir.

Ketujuh, Itsbat al-Zain li Shulh al-Jama'atain bi Jawaz Ta'addud al-Jum'atain fi al-Radd ala al-Kitab al-Musamma Taftih al-Muqillatain fi al-Radd 'ala Sulh al-Jama'atain dalam bahasa Arab. Kitab ini ditulis sebagai bantahan atas tulisan Syekh Sayyid Usman Betawi dalam masalah kebolehan berbilangnya mesjid dalam melaksanakan shalat Jum'at di Palembang dalam satu waktu. Sebelumnya, Syekh Ahmad Khatib menulis kitab dalam bahasa Arab berjudul Sulh al-Jama'atain fi Jawaz Ta'addud al-Jum'atain sebagai balasan atas tulisan Sayyid Usman Betawai yang pertama berjudul Muzil alAuham wa al-Taraddud fi Amr Shalât al-Jum'ah bi al-Ta'addud yang tidak membolehkan berbilangnya shalat Jum'at. Tulisan ini ditulis sebagai jawaban atas pendirian mesjid baru di Palembang untuk melaksanakan shalat Jum'at di samping mesjid lama. Kitab ini selesai ditulis pada tahun $1313 \mathrm{H}$ dan diterbitkan oleh Matba'ah al-Miriyah di Makkah atas biaya adik iparnya, dan dilengkapi dengan "kata pujian" dari empat imam mazhab saat itu.

Kedelapan, Fath al-Mubin liman Salaka Thariq al-Washilin dalam bahasa Jawi. Kitab ini ditulis sebagai bantahan atas tradisi tarekat Naqsyabandiyah dalam masalah "rabithah" yang dianggap menyimpang oleh Syekh Ahmad Khatib. Ada dua versi judul untuk kitab ini, yang pertama dengan judul di atas, dan kedua dengan judul Fath al-Mubin fi Amr min 'Umur al-Dîn. Kitab ini selesai ditulis pada tahun $1318 \mathrm{H}$ dan diterbitkan oleh 
Matba'ah al-Miriyah dan Matba'ah Taraqqi al-Majidiyah di Makkah atas biaya adik iparnya.

Kesembilan, Izhhar Zaghl al-Kadzibin fi Tasyabbuhihim bi al-Shâdiqîn dalam bahasa Jawi. Kitab ini yang pertama sekali menggembarkan alam Minangkabau dalam masalah tarekat. Sebab penulisan kitab ini adalah sebuah surat dari muridnya, Syekh Abdullah Ahmad, pendiri majalah al-Muniryang meminta fatwa terkait lima masalah dalam tarekat Naqsyabandiyah Khalidiyah yang berkembang di Minangkabau. Kelima masalah tersebut adalah sanad Tarekat Naqsyabandiyah Khalidiyah, dasar atas pelarangan mengkonsumsi dalam masa bersuluk, dasar atas pembatasan masa bersuluk 40, 20 dan 10 hari, dasar atas rabithah, dan dasar atas Tarekat Naqsyabandiyah Khalidiyah. Selain memuat jawaban atas lima pertanyaan tersebut, dimuat juga bantahan atas pendapat Syekh Mukhtar Bogor terkait Tarekat Naqsyabandiyah Khalidiyah. Kitab ini selesai ditulis pada tahun $1324 \mathrm{H}$ dan diterbitkan beberapa kali, salah satunya Mathba'ah al-Taqaddum al-'Ilmiyah di Mesir.

Kesepuluh, al-Âyât al-Bayyinat li al-Munsifîn fî Radd Khurafat $B a^{\prime} d h$ al-Muta'ashshibîn dalam bahasa Jawi. Kitab ini ditulis sebagai bantahan atas karya Syekh Muhammad Sa'ad Mungka, ulama senior Kaum Tua Minangkabau yang berjudul Irgham Unuf al-Muta'annitîn fî Inkarihîn Rabithah al-Washilîn dalam bahasa Jawi yang ditulis sebagai bantahan atas kitab Izhhar. Kitab ini selesai ditulis pada tahun $1325 \mathrm{H}$ dan diterbitkan satu paket dengan kitab Izhhar.

Kesebelas, al-Saif al-Battâr fî̀ Mahq Kalimât Ba'dh Ahl alIghtirâr dalam bahasa Jawi. Kitab ditulis atas bantahan sebuah kitab yang penulisnya menyembunyikan nama aslinya. Pembahasan dalam masalah kitab ini masih dalam seputar Tarekat Naqsyabandiyah Khalidiyah. Dengan dua kitab sebelumnya dicetak satu paket 


\section{JOIRNAL OF CONTENPORARY ISLAN AND MISSLIM SOCIETIES}

oleh Mathba'ah al-Taqaddum al-'Ilmiyah dan selesai ditulis pada tahun $1325 \mathrm{H}$.

Keduabelas, al-Khiththah al-Mardiyah fi al-Radd 'alâ Man Yaqûl bî Bid'ah al-Talaffuzh bi al-Niyah dalam bahasa Jawi. Kitab ini ditulis sebagai responsnya atas karya salah satu muridnya, Syekh Abdul Karim Amrullah yang terpengaruh oleh pendapat Imam Ibn Taimiyah dan Imam Ibn al-Qayyim al-Jauziyah dengan menyatakan bahwa mengucapkan ushallî termasuk bidah. Menarik dari kitab ini bahwa Syekh Ahmad Khatib memberikan label sesat kepada kedua ulama tersebut. Kitab ini selesai ditulis pada tahun $1327 \mathrm{H}$ dan diterbitkan oleh Mathba'ah Taraqqi al-Majidiyah di Makkah.

Ketigabelas, Raf'u al-Iltibâs 'an Hukm al-Anwath al-Muta'amal biha Bain al-Nâs dalam bahasa Arab. Kitab ini membahas fatwa fikih terkait diwajibkannya zakat atas uang kertas, dimana ukuran nilai nominalnya sama dengan uang logam (fulus). Kitab ini selesai ditulis pada tahun $1326 \mathrm{H}$ dan diterbitkan oleh Mathba'ah Taraqqi al-Majidiyah di Makkah.

Keempatbelas, Tanbîh al-Anâm fî al-Radd 'alâ Risâlah Kaff al-Awâm 'an al-Khaud fî Syarikah al-Islâm dalam bahasa Arab. Kitab ini ditulis sebagai bantahan atas karangan muridnya, $\mathrm{KH}$. Hasyim Asy'ari yang berjudul Kaff al-'Awâm 'an al-Khaudh fî Syarikah al-Islâm yang menolak keabsahan ormas Sarekat Islam dalam tinjauan agama Islam. Kitab ini selesai ditulis pada tahun 1332 dan pernah dicetak di Mesir dan diperbarui oleh Khazanah Fathaniyah di Kuala Lumpur, Malaysia.

Kelimabelas, Irsyâd al-Hayâri fi Izâlah Ba'dh Syubah alNashârâ dalam bahasa Arab. Kitab ini ditulis sebagai jawaban dari Nusantara berupa kritikan orang Belanda atas 7 masalah dalam agama Islam, yaitu menginkari keberadaan Allah Swt., pologami, talak, penyebaran Islam dengan perang dan paksaan, masalah budah, perbudakan, dan kesalahan agama non-Islam. 
Ketujuh masalah tersebut dijawab Syekh Ahmad Khatib dengan argumentasi yang memuaskan. Kitab ini selesai ditulis pada tahun $1332 \mathrm{H}$ dan diterbitkan di Mesir.

Keenambelas, al-Qaul al-Tahif fî Tarjamah Târîkh Hayâh al-Syaikh Ahmad al-Khatib bin 'Abd al-Lathîf dalam bahasa Arab. Tulisan ini ditulis atas permintaan dari banyak muridnya untuk sebagai pengingat mereka semasa belajar di Makkah terkait biografi dan segala yang berhubungan dengan kehidupan guru mereka. Menarik bahwa kitab ini ditulis ketika Syekh Ahmad Khatib berumur 58 tahun dan dalam keadaan sakit. Kitab ini selesai ditulis pada tahun $1334 \mathrm{H}$ pada tahun wafatnya. ${ }^{28}$

\section{Polemik Pemikiran Tarekat Naqsyabandiyah}

Syekh Ahmad Khatib dikenal dengan ulama yang banyak berpolemik dengan ulama semasanya. Hal ini dapat dilihat dari beberapa karya tulisnya yang menunjukkan perdebatannya dengan ulama lain, semisal dengan Syekh Sayyid Usman Betawi dalam masalah pendirian masjid baru di Palembang untuk salat Jum'at, KH. Hasyim Asy'ari dalam masalah otoritas organisasi Sarekat Islam, Syekh Muhammad Sa'ad Mungka dan beberapa ulama Minangkabau terkait masalah tarekat Naqsyabandiyah, Syekh Abdul Karim Amrullah terkait masalah mengucapkan ushalli, dan masalah pewarisan kemenakan yang sudah menjadi tradisi di Minangkabau juga ikut menambah daftar perdebatannya pada masanya. Namun, karena keterbatasan tempat, dalam tulisan ini hanya memaparkan polemik terkait tarekat Naqsyabandiyah di alam Minangkabau.

Dalam permasalahan ini, Syekh Ahmad Khatib Minangkabau telah menulis empat kitab secara berturut-turut dalam bahasa Jawi-Arab Melayu-yang menunjukkan terus-menerusnya perdebatan yang terjadi dan berjalan dalam tempo waktu yang cukup lama. 


\section{JOIRNAL OF CONTENPORARY ISLAN AND MISSLIM SOCIETIES}

Ketiga kitab tersebut adalah Fath al-Mubîn fîmâ Yata'allaq bi 'Umur al-Dîn, disingkat Fath al-Mubîn, Izhhâr Zaghl al-Kâzibîn fî Tasyabbuhihim bî as-Shadiqîn, disingkat Izhhar, al-Ayat alBayyinât lî al-Munsifîn fî Radd Khurafât Ba'dh al-Muta'assibîn, disingkat al-Âyât al-Bayyinât, dan Al-Saif al-Battar fi Mahq Kalimat $B a^{\prime} d h$ Ahl al-Ightirar, disingkat al-Saif al-Battar. Hal yang melatarbelakangi mengapa ia menulis kitab pertamanya adalah bahwa salah satu tokoh ulama kaum muda yang pernah menjadi muridnya dan pendiri majalah al-Munir, Syekh Abdullah Ahmad menulis surat kepada gurunya di Makkah yang berisi permintaan fatwa terkait tradisi tarekat Naqsyabandiyah yang ada di Minangkabau dan sekaligus dalil-dalil yang menjadi sandaran dalam amaliyah ulama Minangkabau tersebut.

Hal ini senada dengan catatan otobiografi yang ditulisnya yang menyebutkan kitab tersebut ditulis pada tahun $1318 \mathrm{H}$ / 1904 M. ${ }^{29}$ Dalam kitab pertamanya ini, ia menjelaskan istilahistilah yang beredar luas di komunitas ulama tarekat seperti syariat, tarekat dan hakikat. Lebih luas, ia menjelaskan pengertian tarekat yang diajarkan pada masa Nabi Muhammad Saw. berubah secara totalitas pengertian tarekat yang dikenal pada masal ulamaulama pengamal tarekat tersebut. Menurutnya, tarekat yang diajarkan nabi adalah ketersesuaian antara syariat dan tarekat. Dalam memahami tarekat yang benar, para ulama sufi memberikan sembilan wasiat kepada mereka yang ingin menempuh jalan tarekat, yaitu tobat, qana'a $h$, zuhud, belajar ilmu syariat, menjaga sunah dan adab Nabi SAW. baik lahir maupun batin, tawakal, ikhlas, 'uzlah (menghindari dari manusia), dan menjaga waktu yang diberikan dalam ketaatan secara totalitas. Kesembilan wasiat ini dijabarkan secara luas olehnya. Sebagai contoh, ketika menjelaskan pengertian 'uzlah, ia membagi ke dalam dua bentuk. Pertama, apabila orang lain tidak membutuhkannya dalam hal keilmuan dan lainnya, maka sebaiknya ia menjauhi mereka kecuali pada 
waktu salat berjamaah, atau keperluan sehari-hari. Kedua, orang berhajat kepadanya dari keilmuan dan lainnya, maka pada kondisi seperti ini, ia wajib memberikan apa yang mereka butuhkan dari segi agama dan lainnya. ${ }^{30}$

Kesimpulan yang ingin ditekankan Syekh Ahmad Khatib Minangkabau adalah bahwa tarekat yang benar yaitu tarekat Nabi, sahabat, dan ulama-ulama terdahulu yang mengedepankan syariat dalam tarekat. Hal ini berbeda dengan tarekat pada saat itu - di Minangkabau-yang lebih direduksi makna dan pengamalannya dalam bentuk baiat dan wirid yang diajarkan guru mursyid kepada muridnya tanpa memperhatikan dan melalui ilmu-ilmu syariat. Bahkan ia menambahkan bahwa pada masanya tarekat dijadikan alat untuk memupuk harta dan kekayaan dunia. Dengan mengutip pendapat Imam Sya'rani dalam kitab al-Minan alKubra, ia mengatakan bahwa seorang guru mursyid tidak dibenarkan mengajarkan ilmu tarekat apabila ia tidak memiliki keilmuan yang luas dalam bidang syariat. Pendapat ulama sufi besar tersebut diambil terkait banyaknya para guru-guru tarekat pada zaman Syekh Ahmad Khatib Minangkabau ketika menerima murid yang berkeinginan masuk tarekat tidak diseleksi ilmu syariatnya, seperti fardh 'ain. ${ }^{31}$

Pendapat Syekh Ahmad Khatib Minangkabau yang memberikan kritikan kepada amaliyah tarekat Naqsyabandiyah di Minangkabau melalui kitabnya, Fath al-Mubîn dibawa oleh muridnya, Syekh Abdullah Ahmad ke alam Minangkabau dan dipublikasi melalui pengajian-pengajiannya. Berselang tidak berapa lama setelah dikenal publik pendapat-pendapat Syekh Ahmad Khatib Minangkabau, Syekh Muhammad Mukhtar Bogor mengeluarkan pendapatnya terkait tarekat Naqsyabandiyah di Makkah. Fatwanya dialamatkan kepada Syekh Sumpur di Malalo dan berisi pembelaan terhadap tarekat Naqsyabandiyah. 


\section{JOIRNAL OF CONTENPORARY ISLAN AND MISSLIM SOCIETIES}

Pendapat dan fatwa Syekh Muhammad Mukhtar Bogor terkait tarekat Naqsyabandiyah adalah (a) Tarekat Naqsyabandiyah mempunyai dasar hukum, (b) pengikut Tarekat Naqsyabandiyah tidak diperkenankan bertanya terkait dasar hukum, (c) taklid kepada guru Tarekat Naqsyabandiyah sama seperti bertaklid kepada pendiri aliran Asy'ariyah dan Maturidiyah dalam tauhid dan imam empat mazhab dalam fikih, (d) hadis tentang Tarekat Naqsyabandiyah sampai kepada derajat mutawatir, dan (e) sebagian mursyid Tarekat Naqsyabandiyah sampai kepada derajat mujtahid mutlak. Dengan dikeluarkannya pendapat ulama besar Bogor tersebut, membuat dua kelompok dan pengikut di alam Minangkabau antara yang setia mengikuti pendapat Syekh Ahmad Khatib Minangkabau dan sebaliknya menerima fatwa Syekh Muhammad Mukhtar Bogor.

Karena terjadi dua kelompok terkait tarekat, Syekh Abdullah Ahmad memohon izin kepada Syekh Sumpur untuk menunjukkan fatwa Syekh Mukhtar Bogor kepada Syekh Ahmad Khatib Minangkabau di Makkah, ditambah dengan lima pertanyaan yang diajukan kepada gurunya tersebut: (a) apakah Tarekat Naqsyabandiyah mempunyai dasar hukum, (b) apakah silsilah Tarekat Naqsyabandiyah sampai kepada Nabi SAW., (c) apakah tidak mengkonsumsi daging selama persulukan mempunyai dasar hukum, (d) apakah rabithah mempunyai dasar hukum, dan (e) apakah masa persulukan 40, 20, dan 10 hari mempunyai dasar hukum. Fatwa ulama Bogor dan kelima pertanyaan yang dikirim kepada Syekh Ahmad Khatib Minangkabau dijawab dengan menulis kitab yang sangat kontroversi saat itu, Izhar Zaghl al-Kazibîn fî Tasyabbuhihim bîal-Shadiqîn. Peran kitab ini dapat mempengaruhi iklim keagamaan dan ketarekatan di Minangkabau digambarkan langsung oleh rival yang membantah kitabnya, Syekh Muhammad Sa'ad Mungka yang merupakan tokoh senior ulama Kaum Tua dalam kitab berjudul Irgam Unuf al-Muta'annitîn fî Inkarihim Rabithah 
al-Washilinn, disingkat Irgham. Karena penulis tidak menemukan kitab tersebut secara langsung, kitab ini terekam dalam kitab ketiga yang membantah kitab Irgam berjudul al-Âyât al-Bayyinât li al-Munsifin fi Radd Khurafat Ba'dh al-Muta'assibin, disingkat al-Ayat. Syekh Muhammad Sa'ad Mungka mengatakan bahwa dengan diterbitkan kitab Izhar di tengah Minangkabau menyebabkan pertikaian antara dua kelompok yang saling berlawanan sampai kepada aksi mengkafirkan, disebabkan di dalamnya memuat pendapat yang menyerupai pelaku Tarekat Naqsyabandiyah dengan penyembah berhala. ${ }^{32}$

Kitab Izhar memuat dua bantahan: (a) atas fatwa Syekh Mukhtar Bogor dan (b) atas lima pertanyaan Syekh Abdullah Ahmad. Fatwa-fatwa ulama Bogor direspons secara serius oleh pengarang dengan membantah yang diperkuat dengan argumentasiargumentasi kuat. Fatwa pertama ulama Bogor "adanya dasar hukum Tarekat Naqsyabandiyah" dijawab dengan bahwa Nabi SAW. tidak melakukan amalan Tarekat Naqsyabandiyah, dikuatkan dengan tidak dilakukan para sahabat, imam mazhab bahkan ulama hadis tidak mencantumkan amaliyah tersebut di dalam kitab-kitab hadis mereka. ${ }^{33}$ Ia menambahkan amaliyah Tarekat Naqsyabandiyah juga tidak masuk dalam keumuman perintah Allah melalui Alquran dan Hadis. ${ }^{34}$

Fatwa selanjutnya "tidak diperkenankan mengetahui dalilnya dan sejatinya bertaklid kepada guru-guru tarekat, sebagaimana bertaklid kepada imam empat dalam fikih dan pendiri aliran Asy'ariyah dan Maturidiyah dalam tauhid" dijawab olehnya secara jelas. Ia menjawab bahwa segala perbuatan harus dinilai dengan hukum syarak, sehingga apabila tidak ditemukan dalam ajaran syarak, maka diwajibkan mengetahui dalil dari hukum syarak tersebut. Ia melanjutkan bahwa apabila tidak ditemukan sebuah dalil maka dapat dimasukkan dalam pengertian bidah. Dalam masalah menyamakan taklid antara keduanya, Syekh 


\section{JOIRNAL OF CONTENPORARY ISLAN AND MISSLIM SOCIETIES}

Ahmad Khatib Minangkabau menolak penyamaan tersebut. Menurutnya, bertaklid kepada empat imam mazhab adalah bertaklid dalam pengertian kaifiyat, syarat, rukun yang ditetapkan imam mazhab masing-masing, bukan dalam penetapan hukumnya, sebab telah ditetapkan melalui teks Alquran dan Hadis.

Fatwa selanjutnya "hadis terkait Tarekat Naqsyabandiyah sampai kepada derajat mutawatir" dijawab olehnya bahwa ia tidak menemukan satu hadis yang mutawatir terkait masalah ini. Dalam hal ini, ia menjelaskan pengertian hadis mutawatir seperti yang terdapat dalam ilmu hadis. Fatwa selanjutnya "bahwa sebagian guru Tarekat Naqsyabandiyah ada yang sampai derajat mujtahid mutlak" dijawab olehnya bahwa masa setelah imam empat mazhab tidak ditemukan siapa nama-nama mujtahid mutlak.

Sementara jawaban Syekh Ahmad Khatib Minangkabau atas lima pertanyaan yang diajukan muridnya pada intinya memuat hal-hal penting berikut. Pertama, Tarekat Naqsyabandiyah di alam Minangkabau dimasukkan dalam tarekat yang dilakukan Nabi SAW. apabila para guru tarekat mengajarkan lebih dahulu ilmu agama yang mencakup tauhid, fikih dan tasawuf. Tanpa hal tersebut, maka Tarekat Naqsyabandiyah dianggap bidah. Kedua, zikir-zikir yang terdapat dalam Tarekat Naqsyabandiyah tidak sampai sanadnya kepada nabi, seperti zikir isim zat, lathâ'if 'ssyardan lainnya, kecuali zikir talqin zikir. Ketiga, tidak mengkonsumsi daging selama persulukan menyalahi sumber Islam dalam hal makanan. Keempat, Nabi SAW. dan para sahabatnya tidak melakukan amaliyah Tarekat Naqsyabandiyah. Kelima, rabithah yang terdapat dalam Tarekat Naqsyabandiyah tidak memiliki dasar hukum sama sekali. ${ }^{35}$ Di akhir kitab ini, Syekh melampirkan tiga pendapat ulama Makkah yang terkemuka yang menolak otoritas Tarekat Naqsyabandiyah: Syekh Muhammad Said Bafashil, mufti mazhab 
Syâfi'i, Syekh Abdul Karim Dagistan, dan Syekh Syu'aib 'Abdurrahman al-Shadiqi dalam mazhab Maliki. ${ }^{36}$

Di antara reaksi ulama-ulama Minangkabau atas kitab ini adalah menolak secara total yang secara umum berasal dari pengamal Tarekat Naqsyabandiyah ulama Kaum Tua melalui kitab-kitab karya mereka, yaitu Syekh Muhammad Sa'ad Mungka, ${ }^{37}$ Syekh Muhammad Khatib Ali Padang, ${ }^{38}$ Syekh Muhammad Dalil Bayang, ${ }^{39}$ Syekh Sulaiman Rasuli, ${ }^{40}$ dan belakangan dari ulama Aceh, Syekh Muda Wali. ${ }^{41}$

Setelah tersebarnya kitab Izhhar di alam Minangkabau dan ulama yang pertama membantah adalah Syekh Muhammad Sa'ad Mungka melalui karyanya tersebut, ia mengirimnya kepada Syekh Ahmad Khatib Minangkabau di Makkah. Oleh ulama besar asal Minangkabau yang pertama menjadi khatib dan imam di Mesjidilharam ini, ia mengarang sebuah risalah sebagai bantahan atas kitab tersebut yang berjudul al-Âyât al-Bayyinât li al-Munsifîn fî Radd Khurafat Ba'dh al-Muta'ashshibîn. Kitab ini selanjutnya dibantah oleh ulama tersebut dengan sebuah kitab berjudul Tanbih al-Awam 'ala Tagrirat Ba'dh al-Anam. Setelah kitab ini selesai ditulis, Syekh Ahmad Khatib Minangkabau tidak membantah kitab tersebut, namun membantah kitab lain dalam masalah Tarekat Naqsyabandiyah karangan ulama Minangkabau bernama Syekh Abdullah bin Abdullah Mungkar. Untuk membantah kitab ini, ia mengarang kitab al-Saif al-Battâr fî Mahq Kalimat $B a^{\text {'dh }}$ Ahl al-Ightirâr, disingkat al-Saif al-Battâr. ${ }^{42}$

Secara umum, kitab al-Âyât memuat 34 bantahan Syekh Ahmad Khatib atas kitab Syekh Sa'ad Mungka dimulai dengan muqaddimah dan diakhiri dengan pasal rabithah. Dalam kitab ini, isinya senada dengan kitab Izhhar, di mana ia mengulangi argumentasi-argumentasi yang ada di kitab pertama. Menurut Syekh Ahmad Khatib, Syekh Sa'ad Mungka banyak melakukan kekeliruan ketika memahami setiap kalimat dalam kitab Izhhar 


\section{JOIRNAL OF CONTEVPORARY ISLAN AND MISSLIM SOCIETIES}

dalam pengertian ia tidak lengkap menukil kalimat-kalimat yang menjadi dasar bantahannya atas kitab zzhar $^{43}$ Oleh karena kitab al-Ayat bahasan dan argumentasi senada, maka tidak ada dibahas kitab ini seperti kitab Izhhar.

Kitab ketiga, al-Saif al-Battâr memuat sembilan poin penting atas bantahannya terhadap karya Syekh Abdullah bin Abdullah yang sebenarnya bukan nama sebenarnya. Masing-masing dari sembilan poin saling berhubungan antara satu dengan yang lainnya. Di antara bantahannya adalah, pertama, ia membantah dakwaan bahwa dalam kitab pertamanya sebenarnya tidak berpendapat Tarekat Naqsyabandiyah masuk dalam bidah yang diharamkan. Sebab, pembagian bidah masuk dalam lima hukum taklif. Lebih jauh ia menjelaskan bahwa praktik yang ada di Tarekat Naqsyabandiyah tidak mempunyai dasar hukum. Kedua, ia menasihati Syekh Abdullah bin Abdullah untuk mempelajari ilmu fikih terlebih dahulu sebelum menjadi guru Tarekat Naqsyabandiyah sehingga mengetahui pembagian bidah. Ketiga, ia membantah bahwa kitab Izhhar telah membuat instabilitas sosial di Minangkabau. Menurutnya, penyebabnya adalah kekeliruan sebagian orang memahami kitab karangannya. Keempat, ia kembali menguatkan pendapatnya yang pertama bahwa tarekat sebenarnya adalah penguatan seorang guru untuk mengajarkan para muridnya ilmu-ilmu dasar agama Islam. Kelima, ia kembali berpendapat bahwa rabithah sama dengan penyembahan berhala. Sebab, keduanya merupakan jalan untuk mendekatkan diri kepada Allah SWT. ${ }^{44}$

\section{Penutup}

Syekh Ahmad Khatib merupakan seorang tokoh ulama terkemuka Indonesia yang hidup pada akhir abad19 dan awal abad 20 masehi. Ketokohannya dapat dilihat dari dua aspek: pertama, ia telah berhasil melahirkan para murid-murid terkemuka 
yang mempunyai peran penting bagi Indonesia di awal abad 20. Mayoritas murid-murid tersebut merupakan pimpinan keagamaan, baik berupa mufti, kadi, dan syekh Islam di kerajaan maupun pemimpin organisasi keagamaan dan lembaga pendidikan. Kedua, ia telah berhasil menulis banyak karya sebagai respons atas perkembangan keagamaan yang ada di Indonesia saat itu. Karyakaryanya ada yang berbentuk polemik dan ada juga sebagai bahan ajar sampai sekarang di beberapa tempat pengajian. Ketiga, ia sebenarnya tidak anti terhadap tarekat secara umum, namun yang menjadi bahan kritikannya adalah amaliyah yang ada di Tarekat Naqsyabandiyah pada masa itu. Terbukti, ia memberikan tarekat yang diamalkan oleh nabi SAW., para sahabat, dan ulamaulama sufi terkenal di abad-abad silam.

\section{Pustaka Acuan}

Abdullah, Wan Mohd Shagir. Penyebaran Thariqat Muktabarah Sufiyah di Dunia Melayu, cet. 2. Kuala Lumpur: Khazanah Fathaniyah, 2016.

Al-Palimbani, Muhammad Mukhtaruddin bin Zainal Abidin. Bulûgh al-Amani fî al-Tá 'rif bî Syuyûkh wa Asanid Musnid al-Ashr Syekh Muhammad Yasin bin Muhammad Isa alFadani al-Maki. Damaskus: Dâr Qutaibah, 1988.

Al-Jawi, Hasanuddin bin Muhammad Maksum bin Abu Bakar al-Deli. Al-Quthufat al-Saniyah li Man'i Ba'dh Ma fî alFawa'id al-'Âliyah. Makkah: Mathba'ah al-Miriyah al-Ka'inah.

Al-Khatib, Abdul Hamid. Ahmad al-Khatib: Ba'its an-Nahdhah al-Islamiyah fi Indonesia, al-Mudarris wa al-Khatib bi alMasjid al-Haram. t.t.p.: t.p., 1333.

Al-Merbawi,Abdul Manam Bin Mohamad, etal," "Tarekat Naqshabandiyyah Khalidiyyah in Malaysia: A Study on the Leadership of Haji Ishaq bin Muhammad Arif ," dalam MIQOT: Jurnal Ilmu-ilmu Keislaman, Vol. 36, No. 2, 2012. 


\section{JOIRNAL OF CONTENPORARY ISLAN AND MISSLIM SOCIETIES}

Al-Syâfi'i, Ahmad al-Khatib bin 'Abd al-Lathif al-Minangkabawi. Al-Qaul al-Tahif fî Tarjamah Târîkh Hayâh al-Syaikh Ahmad al-Khatib bin 'Abd al-Lathif. t.t.p.: t.p., t.t.

Al-Syâfi'i, Ahmad al-Khatib bin 'Abd al-Lathif al-Minangkabawi. 1344. Izhhar Zaghl al-Kâzibin fî Tasyabbuhihim bi al-Shadiqîn. Mesir: Mathba'ah al-Taqaddum al-'Ilmiyah, 1344.

Al-Syâfi'i, Ahmad al-Khatib bin 'Abd al-Lathif al-Minangkabawi. Al-Saif al-Battar fi Mahq Kalimat Ba'dh Ahl al-Ightirar. Mesir: Mathba'ah al-Taqaddum al-'Ilmiyah, 1345.

Al-Syafi'i, Ahmad al-Khatib bin Abdul Lathif al-Minangkabawi. Al-Ayat al-Bayyinat li al-Munshifîn fî Izalah Khurafat Ba'dh al-Muta 'ashibîn. Mesir: Mathba'ah al-Taqaddum al-'Ilmiyah, 1344.

Al-Syafi'i, Ahmad al-Khatib bin Abdul Lathif al-Minangkabawi. Fathal-Mubin fima Yata'allaq bi 'Umur al-Dîn. Makkah: Mathba'ah al-Miriyah al-Ka'inah, 1321.

Amirul Ulum. Ulama-ulama Aswaja Nusantara yang Berpengaruh di Negeri Hijaz. Yogyakarta: Pustaka Ulama, 2015.

Bruinessen, Martin van. Tarekat Naqsyabandiyah di Indonesia. Bandung: Mizan, 1992.

Erawadi. "Pusat-Pusat Perkembangan Tarekat Naqsyabandiyah di Tapanuli Bagian Selatan,” dalam MIQOT: Jurnal Ilmuilmu Keislaman, Vol. 38, No. 1, 2014.

Fakhriati. "New Light on the Life and Works of Teungku di Pulo: an Acehnese Intellectual in the Late 19th and Early 20th Centuries," dalam MIQOT:Jurnal Ilmu-ilmu Keislaman, Vol. 34, No. 1, 2010.

Hamka. Gerakan Pembaharuan Islam di Minangkabau. Jakarta: Bulan Bintang, 1976.

Ilyas, Ahmad Fauzi. Sebuah Biografi dan Kontribusi Pendidikan Islam di Wilayah Batu Bara (Usuluddin-Fiqih-Tasawuf). Medan: Mitra, 2015. 
Ja'far. "Tarekat dan Gerakan Sosial Keagamaan Shaykh Hasan Maksum," dalam Teosofi: Jurnal Tasawuf dan Pemikiran Islam, Vol. 5, No. 2, 2015.

Al-Jabbâr, 'Umar 'Abd. Siyar wa Tarâjïm Ba'dh 'Ulamîina fî alQarn ar-Râbi' 'Asyar li al-Hijrah, cet. 2. Jeddah: Tuhamah, 1982.

Latif, Muhammad Sanusi. Gerakan Kaum Tua di Minangkabau. Jakarta: Markaz al-Buhûts wa Tathwîr al-Muallafat wa alTurâts al-Dini, 2012.

Matu Mona. Riwajat Penghidoepan al-Fadil: Toean Sjech Hasan Ma'soem (Biografie Sedjak Ketjil Sampai Wafatnja). Medan: Typ Sjarikat Tapanoeli, t.t.

Siregar, L. Hidayat. "Tarekat Naqsyabandiyah Syaikh Abdul Wahab Rokan: Sejarah, Ajaran, Amalan, dan Dinamika Perubahan," dalam MIQOT: Jurnal Ilmu-ilmu Keislaman, Vol. 35, No. $1,2011$.

Steenbrink, A. Beberapa Aspek Tentang Islam di Indonesia Abad ke-19. Jakarta: Bulan Bintang, 1984.

Tim Penulis. Intelektualisme Pesantren, cet. 3. Jakarta: Diva Pustaka, 2006.

Tim Penulis. Sejarah Ulama-ulama Terkemuka Sumatera Utara. Medan: IAIN Sumatera Utara, 1983. 


\section{JOURNAL OF CONTEMPORARY ISLAM ANI MISSIII SOCIETIES}

\section{Catatan Akhir:}

${ }^{1}$ Lihat kajian Erawadi, "Pusat-Pusat Perkembangan Tarekat Naqsyabandiyah di Tapanuli Bagian Selatan," dalam MIQOT: Jurnal IImu-ilmu Keislaman, Vol. 38, No. 1, 2014; L. Hidayat Siregar, "Tarekat Naqsyabandiyah Syaikh Abdul Wahab Rokan: Sejarah, Ajaran, Amalan, dan Dinamika Perubahan,” dalam MIQOT: Jurnal Ilmuilmu Keislaman, Vol. 35, No. 1, 2011; Fakhriati, "New Light on the Life and Works of Teungku di Pulo: an Acehnese Intellectual in the Late 19th and Early 20th Centuries," dalam MIQOT: Jurnal Ilmu-ilmu Keislaman, Vol. 34, No. 1, 2010; Abdul Manam Bin Mohamad al-Merbawi, et al., "Tarekat Naqshabandiyyah Khalidiyyah in Malaysia: A Study on the Leadership of Haji Ishaq bin Muhammad Arif," dalam MIQOT: Jurnal Ilmu-ilmu Keislaman, Vol. 36, No. 2, 2012.

${ }^{2}$ Martin van Bruinessen, Tarekat Naqsyabandiyah di Indonesia(Bandung: Mizan, 1992), h. 98-102.

${ }^{3}$ Wan Mohd Shagir Abdullah, Penyebaran Thariqat Muktabarah Sufiyah di Dunia Melayu, cet. 2 (Kuala Lumpur: Khazanah Fathaniyah, 2016), h. 99-104.

${ }^{4}$ Muhammad Sanusi Latif, Harakah Jamâ'ah al-Syuyûkh fi Minangkabau (Jakarta: Markaz al-Buhûts wa Tathwîr al-Mu'allafat wa al-Turâts al-Dini, 2012), h. 310-311.

${ }^{5}$ Ibid., h. 314.

${ }^{6}$ Hamka, Gerakan Pembaharuan Islam di Minangkabau(Jakarta: Bulan Bintang, 1976), h. 496.

${ }^{7}$ Tim Penulis, Intelektualisme Pesantren, cet. 3 (Jakarta: Diva Pustaka, 2006), h. 85, dan 'Umar 'Abd al-Jabbâr, Siyâr wa Tarâjim Ba'dh Ulamâina fî al-Qarn al-Râbi' 'Asyar li al-Hijrah, cet. 2 (Jeddah: Tuhamah, 1982), h. 38.

${ }^{8} \mathrm{~A}$ hmad al-Khâtib bin 'Abd al-Lathîf al-Minangkabawi al-Syâfi'i, Al-Qaul alTahif fi Tarjamah Târikh Hayâh al-Syaikh Ahmad al-Khatib bin 'Abd al-Lathîf (t.t.p.,: t.p., t.t.), h. 43-45.

"Abd al-Hamid al-Khatib, Ahmad al-Khatib: Bâ'its al-Nahdhah al-Islâmiyah fi Indonisia, al-Mudarris wa al-Khatîb bi al-Masjid al-Harâm (t.t.p.: t.p., t.t.), h. 27.

${ }^{10} \mathrm{Ahmad}$ Fauzi Ilyas, Sebuah Biografi dan Kontribusi Pendidikan Islam di Wilayah Batu Bara (Usuluddin-Fiqih-Tasawuf) (Medan: Mitra, 2015), h. 16.

${ }^{11}$ Amirul Ulum, Ulama-ulama Aswaja Nusantara yang Berpengaruh di Negeri Hijaz (Yogyakarta: Pustaka Ulama, 2015), h. 62-63.

${ }^{12}$ 'Umar 'Abd al-Jabbâr, Siyâr wa Tarâjim, h. 40.

${ }^{13}$ Tentang Syekh Hasan Maksum, lihat kajian Ja'far, "Tarekat dan Gerakan Sosial Keagamaan Shaykh Hasan Maksum," dalam Teosofi: Jurnal Tasawuf dan Pemikiran Islam, Vol. 5, No. 2, 2015, h. 269-293.

${ }^{14}$ Matu Mona, Riwajat Penghidoepan al-Fadil: Toean Sjech Hasan Ma'soem: Biografie Sedjak Ketjil Sampai Wafatnja (Medan: Typ Sjarikat Tapanoeli, t.t.), h. 2324.

${ }^{15}$ Umar 'Abd al-Jabbâr, Siyâr wa Tarâjïm, h. 40. 
${ }^{16}$ Karel A. Steenbrink, Beberapa Aspek tentang Islam di Indonesia Abad ke-19 (Jakarta: Bulan Bintang, 1984), h. 141-145.

${ }^{17}$ Tim Penulis, Intelektualisme Pesantren, h. 88-89.

${ }^{18}$ Hasanuddin bin Muhammad Maksum bin Abu Bakar ad-Deli al-Jawi, AlQuthufat al-Saniyah li Man'i Ba'dh Ma fi al-Fawâ'id al-'Aliyah (Makkah: Mathba'ah al-Miriyah al-Ka'inah, 1333), h. 27-28.

${ }^{19}$ Karel A. Steenbrink, Beberapa Aspek, h. 145.

${ }^{20}$ Hamka, Gerakan Pembaharuan Islam, h. 497.

${ }^{21}$ Karel A. Steenbrink, Beberapa Aspek, h. 140.

${ }^{22}$ Lihat Ahmad Fauzi Ilyas, Sebuah Biografi dan Kontribusi.

${ }^{23}$ Tim Penulis, Sejarah Ulama-ulama Terkemuka Sumatera Utara(Medan: IAIN Sumatera Utara, t.t.), h. 183.

${ }^{24}$ Hamka, Gerakan Pembaharuan Islam, h. 498-499.

${ }^{25}$ Lihat Muhammad Mukhtaruddin bin Zainal Abidin al-Palimbani, Bulugh al-Amani fi al-Ta rif bi Syuyukh wa Asanid Musnid al-Ashr Syekh Muhhammad Yâsin bin Muhammad Isa al-Fâdâni al-Makki (Damaskus: Dâr Qutaibah, 1988), h. 39-40.

${ }^{26}$ Umar 'Abd al-Jabbâr, Siyâr wa Tarâjim, h. 41.

${ }^{27}$ Tim Penulis, Intelektualisme Pesantren, h. 90.

${ }^{28} \mathrm{Ahmad}$ al-Khatib bin Abdul Lathif al-Minangkabawi al-Syâfíi, Al-Qaul, h. 65-85.

${ }^{29}$ Ibid., h. 74.

${ }^{30} \mathrm{Ahmad}$ al-Khatib bin Abdul Lathif al-Minangkabawi al-Syâfíi, Fath al-Mubin fima Yata allaq bi 'Umur al-Dîn (Makkah: Mathba'ah al-Miriyah al-Ka'inah, 1321), h. 17-30.

${ }^{31}$ Ibid., h. 31.

${ }^{32} \mathrm{Ahmad}$ al-Khatib bin Abdul Lathif al-Minangkabawi al-Syâfi'i, Al-Ayat alBayyinat li al-Munshifin fi Izalah Khurafat Ba'dh al-Muta'ashibin (Mesir: Mathba'ah al-Taqaddum al-'Ilmiyah, 1344), h. 6-7.

${ }^{33} \mathrm{Ahmad}$ al-Khatib bin Abdul Lathif al-Minangkabawi al-Syâfi' i, Izhhar Zaghl al-Kadzibin fi Tasyabbuhihim bi al-Shadiqîn(Mesir: Mathba'ah al-Taqaddum al-Ilmiyah, 1344), h. 13.

${ }^{34}$ Ibid., h. 16.

${ }^{35}$ Muhammad Sanusi Latif, Gerakan Kaum Tua di Minangkabau (Jakarta: Markaz al-Buhuts wa Tathwîr al-Muallafat wa al-Turats al-Dini, 2012), h. 320-321.

${ }^{36} \mathrm{Ahmad}$ al-Khatib bin Abdul Lathif al-Minangkabawi al-Syâfi'i, Izhhar, h. 6162.

${ }^{37}$ Lihat Muhammad Sanusi Latif, Gerakan Kaum Tua di Minangkabau h. 324.

${ }^{38}$ Lihat, Miftah al-Shiddiqiyah fi Ishtilah al-Naqsyabandiyah (Padang: Pulobomer, 1905), dan Burhan al-Haq Radd 'ala Tsamaniyah al-Masa'il al-Jawab min Su'al al-Sa'il al-Qath 'iyyah al-Waqi'ah Ghayah al-Taqrib (Padang: Pulobomer, 1918).

${ }^{39} \mathrm{Al}$-Taraghub ila Rahmatillah dan Dar al-Mau izhah. Lihat, Muhammad Sanusi Latif, Gerakan Kaum Tua di Minangkabau, h. 353. 


\section{JOURNAL OF CONTEMPORARY ISLAM ANI MUSLIM SOCIETIES}

${ }^{40}$ Dawa' al-Qulub fi Qishshah Yusuf wa Ya'qub, al-Aqwal al-Wasithah fi al-Dzikr wa al-Rabithah, dan al-Aqwal al-'Aliyah fi al-Thariqah al-'Aliyah (Lihat Muhammad Sanusi Latif, Gerakan Kaum Tua di Minangkabau, h. 362.

${ }^{41}$ Lihat, Permata Intan dan Intan Permata (Banda Aceh: al-Maktabah al-Taufiqiyah al-Sa'adah, t.t.).

${ }^{42} \mathrm{Ahmad}$ al-Khatib bin Abdul Lathif al-Minangkabawi al-Syâfi'i, Al-Saif alBattar fi Mahq Kalimat Ba'dh Ahl al-Ightirar-disingkat al-Saif al-Battar(Mesir: Mathba'ah al-Taqaddum al-'Ilmiyah, 1345), h. 2.

${ }^{43} \mathrm{Ahmad}$ al-Khatib bin Abdul Lathif al-Minangkabawi al-Syâf''i, Al-Ayat, h. 4.

${ }^{44}$ Muhammad Sanusi Latif, Gerakan Kaum Tua di Minangkabau, h. 343-346. 